\title{
ZERDEÇALIN SU İLE EKSTRAKSIYYONUNDA ULTRASES İŞLEMİNİN ETKİSİ VE ELDE EDİLEN EKSTRAKTIN PÜSKÜRTEREK KURUTMA YÖNTEMİYLE ENKAPSÜLASYON KOŞULLARININ OPTİMİZASYONU
}

\author{
Keziban Kübra Güngör, Gülderen Coşgun, Merve Özdemir, Mehmet Torun* \\ Akdeniz Üniversitesi, Mühendislik Fakültesi, Gıda Mühendisliği Bölümü, Antalya, Türkiye
}

Geliş / Received: 01.10.2021; Kabul / Accepted: 27.01.2022; Online bask1 / Published online: 14.02.2022

Güngör, K.K., Coşgun, G, Özdemir, M., Torun, M. (2022). Zerdeçalın su ile ekstraksiyonunda ultrases işleminin etkisi ve elde edilen ekstraktın püskürterek kurutma yöntemiyle enkapsülasyon koşullarının optimizasyonu. GIDA (2022) 47 (1) 107-120 doi: 10.15237/gida.GD21129

Güngör, K.K., Cosgun, G, Özdemir, M., Torun, M. (2022). Influence of ultrasound treatment on turmeric aqueous extraction and optimization of the spray drying conditions for encapsulation of the extract. GIDA (2022) 47 (1) 107120 doi: 10.15237/gida.GD21129

\section{ÖZ}

Bu çalışmada, ülkemizde yetiştirilen zerdeçal rizomlanından fenolik madde ekstraksiyonunda ultrases desteğinin ekstraksiyon süre ve sıcaklığına etkisi araştırılmış, zerdeçal ekstraktının püskürterek kurutma yöntemi ile enkapsülasyonunda bazı işlem parametrelerinin optimizasyonu gerçekleştirilmiştir. Toplam fenolik bileşen miktarının belirlenebilmesi amacıyla geleneksel ekstraksiyon üç farklı sıcaklık $\left(55,75\right.$ ve $\left.95^{\circ} \mathrm{C}\right)$ ve dört farklı sürede $\left(15,30,45\right.$ ve 60 dak.) gerçekleştirilirken, ultrases destekli ekstraksiyon ise; $25^{\circ} \mathrm{C}$ sıcaklıkta, altı farklı sürede (0.5, 1, 2, 3, 4 ve 5 dak.) gerçekleştirilmiştir. Toplam fenolik madde miktarının en yüksek miktarda (1436.68 mg GAE/100 g KM) elde edildiği koşullarda (ultrases destekli, $25^{\circ} \mathrm{C}$ ve 2 dak.) üretilen zerdeçal ekstraktı maltodekstin ve modifiye nişasta kullanılarak püskürterek kurutma yöntemiyle enkapsüle edilmiş, toplam fenolik madde miktarı, kurutma verimi, Carr indeks, Hue açısı ve çözünürlük değerleri kullanılarak optimum işlem şartları belirlenmiştir. Taşıyıcı materyal olarak $\% 15$ maltodekstrin ve $\% 5$ modifiye nişasta karışımının kullanılmasıyla $156^{\circ} \mathrm{C}$ hava giriş sıcaklığında gerçekleştirilen işlem, optimum enkapsülasyon koşulu olarak belirlenmiştir.

Anahtar kelimeler: Zerdeçal (Curcuma longa L.), ultrases, ekstraksiyon, püskürterek kurutma, toplam fenolik içeriği

\section{INFLUENCE OF ULTRASOUND TREATMENT ON TURMERIC AQUEOUS EXTRACTION AND OPTIMIZATION OF THE SPRAY DRYING CONDITIONS FOR ENCAPSULATION OF THE OBTAINED EXTRACT}

\begin{abstract}
In this study, the effect of ultrasound assisted extraction on time and temperature for phenolic extraction from turmeric rhizomes grown in our country was investigated, and some process parameters were optimized in the encapsulation of turmeric extract by spray drying method. For this
\end{abstract}

\footnotetext{
${ }^{*}$ Yazışmalardan sorumlu yazar / Corresponding author;

$\triangle$ torun@akdeniz.edu.tr O (+90) 2423106520 国:(+90) 2423106306
}

Mehmet Torun; ORCID no: 0000-0002-6287-2993

Keziban Kübra Güngör; ORCID no: 0000-0003-2430-4669

Gülderen Coşgun; ORCID no: 0000-0002-6689-943X

Merve Özdemir; ORCID no: 0000-0002-1962-4118 
purpose, conventional extraction at three different temperatures $\left(55,75\right.$ and $\left.95^{\circ} \mathrm{C}\right)$ and four different times $\left(15,30,45\right.$ and $60 \mathrm{~min}$.), ultrasound assisted extraction at $25^{\circ} \mathrm{C}$ in six different times $(0.5,1,2$, 3,4 and 5 min.) was performed to determine the total amount of pheolic substance in the extracts. Turmeric extract, obtained under conditions (ultrasound assisted, $25^{\circ} \mathrm{C}$ and $2 \mathrm{~min}$.) with the highest amount of total phenolic substance (1436.68 mg GAE/100 g DM), was encapsulated by spray drying method using maltodextin and modified starch, and optimum processing conditions were determined by using total phenolic content, drying yield, Carr index, Hue angle and solubility values. Mixture of $15 \%$ maltodextrin and 5\% modified starch as carrier material, also $156^{\circ} \mathrm{C}$ air inlet temperature was determined as optimum conditions.

Keywords: Turmeric (Curcuma longa L.), ultrasound, extraction, spray drying, total phenolic content

\section{GİRİŞ}

"Hint Safranı" olarak da bilinen zerdeçal (Curcuma longa L.) Zingiberaceae familyasindan Asya ve Orta Amerika'da yaygın olarak yetiştirilen çok yıllık bir bitkidir (Patel vd., 2021). Zerdeçal tropikal bir bitki olup, deniz seviyesinden $1500 \mathrm{~m}$ yükseklikte, y1llık sicaklığın $20-35^{\circ} \mathrm{C}$ arasında değiştiği, kumlu veya killi-tınlı topraklara sahip bölgelerde verimli bir şekilde yetiştirilebilmektedir (Hailemichael ve Zakir, 2021). Hindistan, dünya zerdeçal üretiminin \%78'lik kısmını tek başına gerçekleştirirken \%8'lik üretimle Çin, ikinci sırada yer almakta ve onu Myanmar, Nijerya ve Bangladeş takip etmektedir (Singh vd., 2020). Özellikle Orta Doğu ve Asya ülkelerinde baharat olarak kullanımı yaygın olan zerdeçalın geçmişten bu yana Çin, Hindistan ve Endonezya gibi ülkelerde bitkisel ilaç karışımlarında da sıklıkla yer aldığ1 bildirilmektedir (Tayyem vd., 2006). Endüstriyel olarak ise günümüzde zerdeçalın renk, lezzet ve biyoaktif özelliklerinden dolay1 g1da, g1da takviyesi, kozmetik, eczacilık ve tekstil sektörlerinde kullanıldığ görülmektedir. Zerdeçalın kullanılan kısımları olan rizomları, hasadı takiben genellikle kurutulup toz forma dönüştürülerek mikrobiyolojik ve kimyasal açıdan güvenli bir yapının kazandırılması sağlanmaktadır (Komonsing vd., 2021). Kuru zerdeçal rizomları makro bileşenler açısından incelendiğinde $\% 69.43$ karbonhidrat, $\% 6.3$ protein, $\% 5.1$ yağ ve $\% 3.5$ mineral (Tanvir vd., 2017) içermekle birlikte, zerdeçalın biyoaktif özellikleri temel olarak içeriğindeki fenolik maddelerden ileri gelmektedir. Zerdeçal rizomlarında en fazla bulunan ve ürünün sarı renginden de sorumlu olan fenolik maddeler kurkuminoidler olup bunlar içerisinde en önemlisi yaklaşık \%2-6 oranında bulunan kurkumindir. Demetoksikurkumin ve bismetoksikurkumin kurkuminden sonra zerdeçaldaki önemli diğer kurkuminoid yapıdaki bileşenler olup (Komonsing vd., 2021), kurkuminoidlerin antioksidan, antibakteriyel, antienflamatuar (Yang vd., 2020), anti-HIV (Mathew ve Hsu, 2018), antitümör, antikanser ve antiviral (Zhang vd., 2015) etkilerinin olduğu bildirilmektedir.

Bahsedilen önemli biyolojik etkilerinden dolay1 gıda, ilaç ve kozmetik gibi alanlarda kullanımı yaygin olan kurkuminoidlerin zerdeçaldan esktrakte edilip stabil bir formda üretilmesi ekonomik anlamda oldukça önemli görülmektedir. Nitekim, bitki materyallerinden fenolik bileşikleri verimli bir şekilde kazanabilmek için mikrodalga destekli ekstraksiyon, ultrases destekli ekstraksiyon (UDE) ve süperkritik $\mathrm{CO}_{2}$ ekstraksiyonu dahil olmak üzere çeşitli yeni ekstraksiyon teknikleri geliştirilmiştir (Banozic vd., 2020). UDE çevre dostu, kolay uygulanabilir ve ucuz olması nedeniyle diğer ekstraksiyon teknikleri içerisinde dikkat çekmektedir. Ultrases dalgaları uygulandığ1 materyallerin fiziksel ve kimyasal özelliklerini değiştirmekte, oluşan kavitasyon etkisiyle ekstrakte edilebilir bileşiklerin salınımı kolaylaşmakta ve bitki hücre yapısının bozulmasıyla kütle transferi kolaylaşmaktadır. Ekstraksiyon sirasında ultrasesin bir diğer etkisi ise bitki dokularında erozyon olarak adlandırılan bölgesel hasara yol açması ve bu şekilde bitki matrisinde çözücünün difüzyonunu arttırmasıdır (Güngör, 2021).

Zerdeçal ekstraktının kolay kullanılabilir bir formda bulunması ve enkapsüle edilerek 1sı, 1şık, oksijen vb. çevre koşullarına karşı yüksek depolama stabilitesine sahip olması özellikle gida endüstrisi açısından tercih edilebilirliğini arttırmaktadır. Bu amaçla sıvı bir ürünün atomizer yardımı ile sıcak bir hava ortamına verilerek 
aniden toz forma dönüştürülmesi işlemi olan püskürterek kurutma yaygın bir şekilde kullanılmaktadır. Püskürterek kurutma işlem şartları (kurutma havası giriş ve çıkış sıcaklığı, besleme oran1, aspirasyon hizı) ve kurutma sırasında kullanılan taşıyıcı materyalin özellikleri son ürünün kalitesi üzerinde önemli etkilere sahiptir. Püskürterek kurutma işleminde genellikle kullanılan taşıyıcı maddeler; proteinler (sodyum kazeinat, peyniraltı suyu proteini, jelatin), gamlar (gam arabik, sodyum aljinat, karragenan, guar gam), selülozlar (metilselüloz, etilselüloz vb.) ve karbonhidratlardır (maltodekstrinler, modifiye nişasta, siklodekstrinler) (Balc1-Torun, 2019). Püskürterek kurutmada kullanılan taşıyıcı maddelerde iyi bir film oluşturma, yüksek konsantrasyonlarda düşük viskozite gösterme, yüksek çözünürlük ve düşük maliyet temel olarak aranan özelliklerdendir. Tek bir taşıyıcı maddenin tüm bu özelliklere sahip olması zor olduğu için, taşıyıcı maddelerin bir arada kullanılması ile istenilen özellikler sağlanabilmektedir (ÖzgünerKabak, 2019). Püskürterek kurutma işleminde nişastanın kısmi hidrolizinden türetilen bir polisakkarit olan maltodekstrin (MD) en fazla kullanılan taşıyıcı maddelerden biridir. MD nispeten düşük maliyet, nötr tat, yüksek konsantrasyonlarda düşük viskozite ve oksidasyona karşı iyi koruma gibi avantajlara sahip olmasina rağmen, emülsifiye edici kapasitesinin düşük olmasından dolayı özellikle aroma salınımının da minimize edilmek istendiği oleoresin gibi bitki ekstraktı karışımlarında arap zamk1, modifiye nişasta ve proteinler gibi diğer taşıyıcılarla birlikte kullanımı tercih edilmektedir (Carneiro vd., 2013).

Literatür incelendiğinde zerdeçal ekstrakt1 ve oleoresinlerinin maltodekstrin (Coronel-Delgado vd., 2017), peyniralt1 suyu proteini (Gomes vd., 2020), arabik gam (Aniesrani Delfiya vd., 2014, Bucurescu vd., 2018), maltodekstrin/arabik gam karışımı (Papillo vd., 2019), maltodekstrin/arabik gam/modifiye nişasta karışımı (Cano-Higuita vd., 2015), pullulan (Kshirsagar vd., 2009), maltodekstrin ve Hi-Cap (Patel vd., 2021), maltodekstrin/jelatin karışımı (Ferreira vd., 2019), arabik gam/peyniraltı suyu proteini ve maltodekstrin/peyniraltı suyu proteini karışımları
(Köprüalan vd., 2021), pektin, maltodekstrin, ksantan gam ve inülin (Goëlo vd., 2020) gibi taşıyıcı maddeler kullanılarak püskürterek kurutma yöntemiyle toz forma dönüştürüldüğü çalışmalar mevcuttur. Yapılan bu çalışmada ise benzer makalelerden farklı olarak taşıyıcı madde karışımları (maltodekstrin ve modifiye nişasta) ile birlikte püskürterek kurutma sıcaklığı da bağımsız bir değişken olarak ele alınmış olup bu faktörlerin kurutma verimi yanında zerdeçal ekstraktının çözünürlük, Hue açısı ve Carr indeks değerleri ile toplam fenolik madde miktarı üzerindeki etkisi incelenmiştir.

\section{MATERYAL VE YÖNTEM \\ Materyal}

Çalışma kapsamında kullanılan zerdeçal (Curcuma longa L.) örnekleri Antalya'nın Gazipaşa ilçesinde bulunan yerel bir üreticiden temin edilmiştir. Örnekler kullanılmadan önce soğuk su ile yıkanmış, kabukları soyulmuş ve dondurulduktan sonra vakum altında kurutulmuştur. Analizlerde kullanilan kimyasallar Sigma-Aldrich (Darmstadt, Almanya) ve Merck (Darmstat, Almanya) firmalarından temin edilmiştir.

\section{Dondurarak Kurutma}

Zerdeçal örnekleri $-80^{\circ} \mathrm{C}$ 'deki dondurucuda 6 saat boyunca dondurma işlemine tabi tutulmuş olup ardindan dondurucudan alınan örnekler, dondurarak kurutma yöntemiyle (OPERON FDU\&FDB, Kore) $40 \mathrm{mmHg}$ mutlak basınçta nem değeri yaklaşık \%3'e gelinceye kadar 30 saat süreyle kurutulmuştur. Bu şartlar yapılan ön denemeler sonucunda belirlenmiştir. Kurutulan örnekler daha sonra ekstraksiyonda homojen partikül boyutu sağlamak amaciyla 500 $\mu$ m'lik eleklerden geçirilmiş ve elekten geçen toz ürün ile çalışmalara devam edilmiştir.

\section{Geleneksel ekstraksiyon}

Zerdeçal örneklerinin geleneksel yöntemle ekstraksiyonunda çözgen olarak saf su kullanılmış, katı:su $(1: 100 \mathrm{~g} / \mathrm{mL})$ oranı daha önce bitki ekstraksiyonu üzerine yapmış olduğumuz çalışma (Torun vd., 2015) ve kullanılan katının sivi ile yeterli teması göz önünde bulundurularak belirlenmiştir. Ekstraksiyonun en uygun sicaklık 
ve süre değerlerini belirlemek amactyla ise üç farklı sıcaklık $\left(55,75\right.$ ve $\left.95^{\circ} \mathrm{C}\right)$ ve dört farklı sürede $(15,30,45$ ve 60 dak.) çalkalamalı su banyosunda (Daihan WSB-30) 100 mL'lik cam kavanozlar içerisinde $150 \mathrm{rpm}$ karıştırma hızında çalışmalar gerçekleştirilmiştir. Ekstraksiyon işleminden sonra örnekler, kaba filtre kağıdından (gözenek çap1 2-4 $\mu \mathrm{m}$ ) süzülmüş, ardından oda sıcaklığına gelmeleri sağlanmış ve toplam fenolik madde analizi için kullanılmıştır.

\section{Ultrases destekli ekstraksiyon}

Ekstraksiyon süresini kısaltmak ve yüksek sicaklıklarda ekstraksiyon sırasında oluşabilecek biyoaktif madde degradasyonlarını engellemek için çalşmada $25^{\circ} \mathrm{C}$ 'de ultrases destekli ekstraksiyon işlemi gerçekleştirilmiştir. Bu işlem $(1: 100 \mathrm{~g} / \mathrm{mL})$ oranında zerdeçal:saf su kullanılarak, sabit genlikte (\%55), altı farklı sürede (0.5, 1, 2, 3, 4, 5 dak.), $13 \mathrm{~mm}$ problu ve $20 \mathrm{kHz}$ sabit frekansta çalışan ultrases cihazı (VC750, 750 W, Sonic and Materials, Inc., Mewtown, Conn., A.B.D.) kullanılarak gerçekleştirilmiştir. Ekstraksiyon sırasinda sicaklığı sabit tutabilmek için çift cidarlı beher kullanılmış ve su sirkülasyonu su banyosuyla (RW-3025 Lab Copanion, Kore) sağlanmışır. Ekstraksiyon işleminin ardından alınan örnekler kaba filtre kağıdından (gözenek çapı 2-4 $\mu \mathrm{m}$ ) süzülerek toplam fenolik madde analizi için kullanılmıştır.

\section{Püskürterek Kurutma}

Toplam fenolik madde miktarının en yüksek bulunduğu şartlarda elde edilen ekstrakt laboratuvar ölçekli (Büchi Mini Püskürtmeli Kurutucu, B-290, İsviçre) püskürterek kurutucuda enkapsüle edilmiş ve taşıyıcı madde seçimi ile püskürterek kurutma sıcaklı̆̆ı Design Expert 10 paket programında cevap-yüzey metodu kullanılarak olușturulan deneme desenine göre optimize edilmiştir. Kurutma işlemi öncesinde ekstraktın \%20'si kadar taşıyıc1 materyal (maltodekstrin ve modifiye nişasta) kullanılmış ve kullanılan materyallerin karışım içerisindeki oranı bağımsız değişkeni oluşturmuştur. Ayrıca bir diğer bağımsız değişken olan püskürterek kurutma giriş sıcaklığ $\mathrm{da}$ faktöriyel olarak üç noktada $\left(135,150\right.$ ve $\left.165^{\circ} \mathrm{C}\right)$ desene katılmış, kurutma işlemlerinde besleme oran1 (400-600 mL/saat), çıkış sıcaklığ $\left(85^{\circ} \mathrm{C}\right)$ ve aspirasyon hiz1 (\%85) sabit tutulmuştur. Örneklerin su aktivitesi değeri 0.2-0.3 aralığında olacak şekilde kurutma işlemi yapılmış ve cevap olarak kurutma verimi ile elde edilen mikrokapsüllerin toplam fenolik madde miktar1, çözünürlük, Carr indeks ve Hue açısı değerleri kullanılmıştır.

\section{Toplam fenolik madde tayini}

Elde edilen ekstraktlarda ve toz ürünlerde toplam fenolik madde miktarı Škerget vd. (2005)'e göre spektrofotometrik yöntemle yapılmıştır. Bu amaçla, elde edilen ekstraktlardan ön çalışma ile elde edilen seyreltme oranından $0.5 \mathrm{~mL}$ örnek cam tüpler içerisine aktarılmış, üzerine $2.5 \mathrm{~mL}$ Folin-Ciocalteu çözeltisi (\%10'luk) ve $2 \mathrm{~mL}$ \% 7.5'lik $\left(\mathrm{Na}_{2} \mathrm{CO}_{3}\right)$ çözeltisi eklenmiştir. Elde edilen karışım vorteksle (DragonLab, MX-S) $30 \mathrm{~s}$ karıştırıldıktan sonra $50^{\circ} \mathrm{C}$ 'deki su banyosunda 5 dak bekletilmiştir. Daha sonra su banyosundan alınan örnekler karanlık bir ortamda 10 dak bekletildikten sonra spektrofotometrede (Shimadzu UV-vis 160A) $760 \mathrm{~nm}$ dalga boyunda absorbansları okunmuştur. Elde edilen absorbans değerleri gallik asit çözeltileri ile oluşturulan eğri yardımıyla mg gallik asit eşdeğeri (GAE)/g kuru örnek ağırlığına dönüştürülmüştür. Aynı işlemler mikrokapsüllerin \%1 (ağırlık/hacim) saf su içerisinde çözündürülmesiyle elde edilen ekstraktlarda da yapılarak mikrokapsüllerin fenolik madde miktarları hesaplanmıştır.

\section{Kurutma verimi}

Püskürterek kurutma yöntemi ile elde edilen zerdeçal mikrokapsüllerinin verim değerleri, son ürün miktarının beslenen karışımdaki kuru madde miktarına oranlanmasıyla hesaplanmıştır (Şahin-Nadeem vd., 2011).

\section{Çözünürlük analizi}

Mikrokapsüllerin çözünürlük analizinde ŞahinNadeem vd. (2011)'in uyguladığ1 yöntem kullanılmıştır. Bu doğrultuda $0.50 \pm 0.001 \mathrm{~g}$ örnek tartılarak üzerine $50 \mathrm{~mL}$ su ilave edilmiş ve 5 dakika 600d/dak'da manyetik karıştırıcıda (Jeio Tech MS-32M) karıștırilmıștır. Elde edilen çözeltiler santrifüj tüplerine aktarıldıktan sonra 3000 g'de 5 dakika santrifüj (Herolab Unigen 
MR, Germany) edilmiştir. Santrifüj sonrası üstte kalan fazdan $20 \mathrm{~mL}$, daras1 alınan petrilere aktarılarak $70^{\circ} \mathrm{C}$ 'de sabit tartıma gelinceye kadar bekletilmiş ve çözünürlük, (\%) ağırlık farkından hesaplanmıştır.

\section{Carr indeks değerinin hesaplanması}

Mikrokapsüllerin yığın ve sıkıştırılmış yoğunluk sonuçlarından aşağıdaki eşitlik kullanılarak Carr indeks (CI) değerleri hesaplanmıştır.

$\mathrm{CI}=(\varrho \mathrm{t}-\varrho \mathrm{b}) / \varrho \mathrm{t}) \times 100$

(Eşitlik 1)

Eşitlikte @b, örneklerin yı̆̆ın yoğunluğu değerlerini $\left(\mathrm{kg} / \mathrm{m}^{3}\right)$; @t ise sıkıştırılmış yoğunluk değerlerini $\left(\mathrm{kg} / \mathrm{m}^{3}\right)$ ifade etmektedir. Mikrokapsüllerin yığın yoğunluğu $10 \mathrm{~mL}$ 'lik mezür içerisinde hava boşluğu kalmayacak şekilde, herhangi bir basınç uygulamaksızın $2 \mathrm{~g}$ tartıldıktan sonra kütle/hacim oraninda hesaplanmıştır (Bhandari vd., 1992; Koç 2015). Sıkıştırılmış yığın yoğunluğu ise $2 \mathrm{~g}$ toz örneğin tartıldığ1 silindirik kabın 35 defa (toz ürünlerin arasında oluşan boşlukların kaybolması için) manuel olarak sert bir zemine vurulup sıkıştırıldıktan sonraki hacim okunarak yine kütle/hacim oranından hesaplanmıştır (Beristan vd., 2001).

\section{Renk analizi}

Püskürterek kurutma işlemi sonrasında elde edilen enkapsüle zerdeçal örneklerinin $\% 1$ (ağırlık/hacim)'lik sulu ekstraktlarının renk değerleri Konica-Minoltaa CR-400 renk ölçer cihazı kullanılarak ölçülmüş, ölçülen a (yeşillikkırmızılık) ve b (mavilik-sarılık) renk değerleri üzerinden örneklerin Hue açısı $\left(b^{\circ}\right)$ değerleri aşağıdaki eşitlik kullanılarak hesaplanmıştır (Şahin-Nadeem vd., 2011).

$h^{\circ}=\frac{180}{\pi} \times \tan ^{-1}(\mathrm{~b} / \mathrm{a})$

(Eşitlik 2)

\section{İstatistiksel analiz}

Ekstraksiyon sonucunda elde edilen sonuçların ortalamalarına varyans analizi uygulanmış, önemli bulunan farklılıklar Duncan Çoklu Karşılaştırma Testi ile ortaya koyulmuştur. Varyans analizi ve Duncan Çoklu Karşılaştırma Testi SAS Institute (Cary, NC, ABD) tarafindan hazırlanan "The SAS system for Windows V7" isimli istatistiksel yazılım programı kullanılarak yapılmıştır. Püskürterek kurutma işleminin optimum koşullarının belirlenebilmesi için Design-Expert Paket Programı (Stat-Ease Inc., Version 10, Minneapolis, ABD) kullanılmış, sonuçlar ANOVA analizi ile değerlendirilmiştir.

\section{BULGULAR VE TARTIŞMA}

Ekstraksiyon şartlarının toplam fenolik madde miktarı üzerine etkisi

Suda çözünür zerdeçal mikrokapsüllerinin üretiminde ilk aşama ekstraksiyon olup suya geçebilecek fenolik maddelerin en yüksek oranda alınabilmesi ekstraksiyondan sonraki aşamaların verimliliği açısından önem arz etmektedir. Bu nedenle geleneksel yöntemle farklı sicaklıklarda $\left(55,75\right.$ ve $\left.95^{\circ} \mathrm{C}\right)$ ve sürelerde $(15,30,45$ ve 60 dak.), ultrases destekli yöntemde ise oda sicaklığında $\left(25^{\circ} \mathrm{C}\right)$ farklı sürelerde $(0.5,1,2,3,4$ ve 5 dak.) ekstraksiyonlar gerçekleştirilmiştir. Geleneksel yöntemle yapilan ekstraksiyon sonucunda elde edilen ekstraktların toplam fenolik madde miktarı değerleri sıcaklık ve süreye bağlı olarak 563.70-1371.408 mg GAE/100 g kuru madde (KM) arasında değişim göstermiştir (Şekil 1).

Ekstrakte edilebilir fenolik madde miktarının ekstraksiyon sıcaklığı ve süresi ile artış gösterdiği, 55 ve $75^{\circ} \mathrm{C}$ lerde yapılan ekstraksiyon işleminin toplam fenolik madde miktarı üzerinde 15. dakikadan sonra istatistiki açıdan $(P>0.05)$ önemli olmadığı görülmüsstür. Sana vd. (2019) tarafindan zerdeçal rizomlarından su ile yapılan ekstraksiyon sonucunda ekstraktların toplam fenolik madde miktarının 60. dakika sonunda $889.63 \mathrm{mg}$ olduğu belirlenmiştir. Yine benzeri bir çalışmada zerdeçal rizomlarının $25^{\circ} \mathrm{C}$ 'de 1 saat süreyle yapilan esktraksiyonu sonucu elde edilen su ekstraktının toplam fenolik madde miktarı $496.76 \mathrm{mg}$ GAE/100 g KM olarak bulunmuştur (Nisar vd., 2015). Rapor edilen sonuçlarla çalışmamızda elde edilen sonuçlar kısmen benzerlik göstermekle birlikte aradaki farklilikların materyal ile ekstraksiyon şartlarından (besleme oranı, sıcaklık, karıştırma hızı vb.) ileri geldiğini söylemek mümkündür. Şekil 1'de verilen sonuçlar incelendiğinde ultrases desteğiyle geleneksel yönteme göre çok daha düşük sicaklıkta $\left(25^{\circ} \mathrm{C}\right)$ ve 
kısa sürede (2 dak.) daha fazla fenolik maddenin (1436.68 mg GAE/100 g KM) ekstrakte edilebildiği görülmektedir. Bu durum ultrases sonucu oluşan kavitasyonla hücre duvarının parçalanarak fenoliklerin kütle transferinin artmasıyla ilişkilendirilmektedir (Yang vd., 2020).
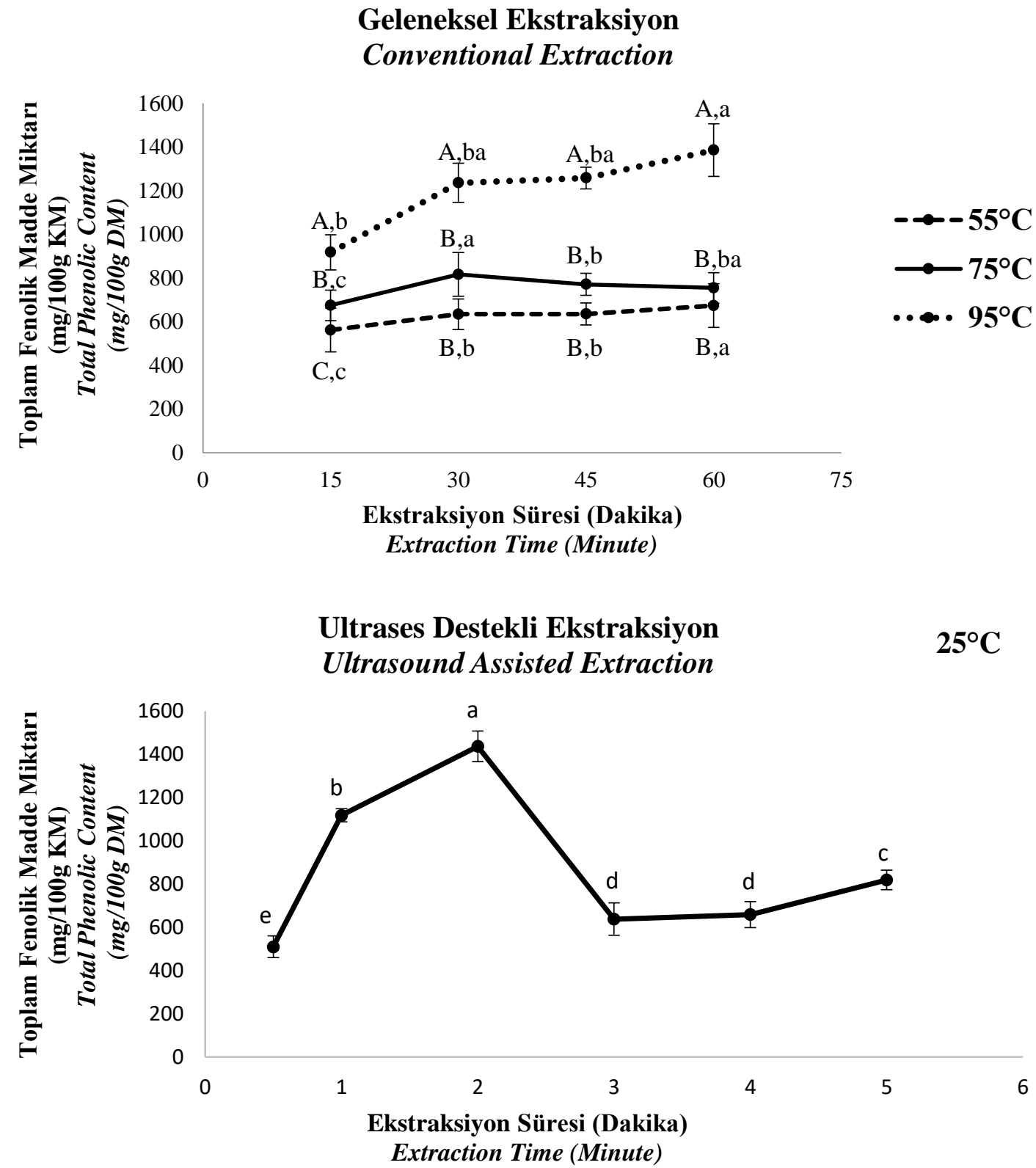

Şekil 1. Ekstraksiyon koşullarının toplam fenolik madde miktarı üzerine etkisi. Farklı harfler $P<0.05$ seviyesinde ekstraksiyon süresine ve sıcaklığına bağlı farklılıkları ifade etmektedir.

Figure 1. Influence of extraction conditions on total phenolic content. Different letters indicate differences at the $P<0.05$ level depending on the extraction time and temperature. 
Püskürterek Kurutma Koşullarının Optimizasyonu

En fazla fenolik madde miktarının elde edildiğ koşullarda $\left(25^{\circ} \mathrm{C}\right.$ 'de 2 dakika süreyle ultrases destekli ekstraksiyon) üretilen zerdeçal ekstraktı cevap-yüzey metoduna göre oluşturulan deneme desenine göre püskürterek kurutma yöntemiyle enkapsüle edilmiş, optimum koşullar toplam fenolik madde miktarı (en yüksek), kurutma verimi (en yüksek), Carr indeks (en düşük), Hue açıs1 ve çözünürlük (en yüksek) değerleri kullanılarak belirlenmiştir. Deneme desenine göre üretilen zerdeçal mikrokapsüllerinin test edilen özelliklerine ait sonuçlar Çizelge 1'de ve bağımsız değişkenlerin bu özellikler üzerine etkisini gösteren ANOVA tablosu ise Çizelge 2'de verilmiştir.

Çizelge 1. Zerdeçal mikrokapsüllerinin bazı özellikleri üzerine püskürterek kurutma koşullarının etkisi Table 1. Influence of spray drying conditions on some properties of turmeric microcapsules

\begin{tabular}{|c|c|c|c|c|c|c|c|c|c|}
\hline $\begin{array}{l}\text { Deneme } \\
\text { Experiment }\end{array}$ & $\begin{array}{l}\mathrm{MD} \\
(\%) \\
M D \\
(\%)\end{array}$ & $\begin{array}{l}\mathrm{MN} \\
(\%) \\
M S \\
(\%)\end{array}$ & $\begin{array}{c}\text { Sicaklik } \\
\left({ }^{\circ} \mathrm{C}\right) \\
\text { Temperature } \\
\left({ }^{\circ} \mathrm{C}\right)\end{array}$ & $\begin{array}{c}\mathrm{Su} \\
\text { aktivitesi } \\
\left(\mathrm{a}_{\mathrm{w}}\right)\end{array}$ & $\begin{array}{c}\text { Toplam fenolik } \\
\text { madde miktar1 } \\
(\mathrm{mg} / 100 \mathrm{~g} \\
\text { mikrokapsül) } \\
\text { Total phenolic content } \\
\text { (mg/100 g microcapsule) }\end{array}$ & $\begin{array}{l}\text { Verim } \\
(\%) \\
\text { Yield } \\
(\%)\end{array}$ & $\begin{array}{c}\text { Carr } \\
\text { indeks } \\
\text { Carr index }\end{array}$ & $\begin{array}{c}\text { Hue } \\
\text { açis1 } \\
\left(\mathrm{h}^{\circ}\right) \\
\text { Hue } \\
\text { angle }\left(b^{\circ}\right)\end{array}$ & $\begin{array}{c}\text { Çözünürlük } \\
(\%) \\
\text { Solubility } \\
(\%)\end{array}$ \\
\hline 1 & 20 & 0 & 165 & 0.1925 & 262.00 & 87.80 & 28.38 & 86.18 & 100.00 \\
\hline 2 & 15 & 5 & 150 & 0.2298 & 464.16 & 91.92 & 23.00 & 87.18 & 100.00 \\
\hline 3 & 20 & 0 & 135 & 0.1312 & 246.77 & 78.41 & 23.89 & 87.18 & 98.60 \\
\hline 4 & 0 & 20 & 135 & 0.1022 & 325.92 & 70.22 & 26.13 & 93.35 & 97.88 \\
\hline 5 & 10 & 10 & 135 & 0.1641 & 301.27 & 76.36 & 28.58 & 92.23 & 99.48 \\
\hline 6 & 0 & 20 & 150 & 0.1236 & 418.55 & 70.80 & 25.00 & 92.76 & 94.15 \\
\hline 7 & 5 & 15 & 135 & 0.1242 & 311.07 & 70.74 & 25.98 & 92.61 & 97.70 \\
\hline 8 & 10 & 10 & 150 & 0.1877 & 359.24 & 90.96 & 24.68 & 91.10 & 96.28 \\
\hline 9 & 0 & 20 & 150 & 0.1345 & 372.30 & 81.44 & 26.38 & 91.74 & 93.10 \\
\hline 10 & 20 & 0 & 150 & 0.1514 & 353.99 & 98.92 & 19.70 & 90.02 & 99.00 \\
\hline 11 & 10 & 10 & 165 & 0.2335 & 292.66 & 85.04 & 20.75 & 89.67 & 98.60 \\
\hline 12 & 0 & 20 & 165 & 0.2971 & 305.72 & 88.28 & 24.10 & 88.26 & 91.70 \\
\hline 13 & 10 & 10 & 150 & 0.1287 & 363.60 & 93.15 & 24.68 & 89.85 & 98.80 \\
\hline
\end{tabular}

MD: Maltodekstrin, MN: Modifiye nişasta, MD: Maltodextrin, MS: Modified starch

Çizelge 2. Püskürterek kurutma yöntemiyle elde edilen zerdeçal mikrokapsüllerinin bazı kalite özellikleri üzerine bağımsız değişkenlerin etkisini gösteren ANOVA sonuçları

Table 2. ANOVA results showing the effect of independent variables on some quality characteristics of turmeric microcapsules obtained by spray drying method

\begin{tabular}{|c|c|c|c|c|c|c|}
\hline $\begin{array}{l}\text { Parametreler } \\
\text { Parameters }\end{array}$ & & $\begin{array}{l}\text { Toplam fenolik } \\
\text { madde miktar1 } \\
\text { Total phenolic } \\
\text { content }\end{array}$ & $\begin{array}{l}\text { Kurutma } \\
\text { verimliliği } \\
\text { Dryingyield }\end{array}$ & $\begin{array}{l}\text { Carr } \\
\text { indeks } \\
\text { Carr } \\
\text { index }\end{array}$ & $\begin{array}{l}\text { Hue açis1 } \\
\left(\mathrm{h}^{\circ}\right) \\
\text { Hue angle } \\
\left(b^{\circ}\right)\end{array}$ & $\begin{array}{l}\text { Çözünürlük } \\
(\%) \\
\text { Solubility } \\
(\%)\end{array}$ \\
\hline \multirow{2}{*}{$\begin{array}{l}P \text { değeri } \\
P \text { value }\end{array}$} & $\begin{array}{l}\text { Model } \\
\text { Model }\end{array}$ & 0.0033 & 0.0019 & 0.0229 & 0.0048 & 0.0417 \\
\hline & $\begin{array}{l}\text { Model uyumsuzluğu } \\
\text { Lack of fit }\end{array}$ & 0.2721 & 0.8775 & 0.2386 & 0.2388 & 0.6109 \\
\hline & & 0.6811 & 0.9040 & 0.9496 & 0.7458 & 0.9307 \\
\hline $\begin{array}{l}\text { Düzeltilmiş } \mathrm{R}^{2} \\
\text { Adjusted } \mathrm{R}^{2}\end{array}$ & & 0.6174 & 0.8355 & 0.8489 & 0.6610 & 0.7922 \\
\hline
\end{tabular}


Model uyumsuzluğu tüm özellikler için önemsiz bulunurken, model toplam fenolik madde miktar1, kurutma verimi ve Hue açısı değerleri üzerinde $P<0.01$ seviyesinde; Carr indeks ve çözünürlük değerleri üzerinde ise $P<0.05$ seviyesinde önemli bulunmuştur. Her bir özellik için önerilen model denkleminin $R^{2}$ değerleri 0.6811-0.9496; düzeltilmiş $R^{2}$ değerleri ise 0.6174-0.8489 arasında bulunmuştur. Regresyon katsayısı $R^{2}$, deneysel verideki model tarafindan açıklanabilen varyasyonun toplam varyasyona oranı olarak tanımlanmaktadır. Ancak modele yeni terimlerin eklenmesi, bu terimler istatistiksel olarak önemsiz olsa da $R^{2}$ yi her zaman arttırmaktadır. Bu nedenle düzeltilmiş regresyon katsayısı (düzeltilmiş $R^{2}$ ) değerlerinin modelin uygunluğunun değerlendirilmesinde kullanılması önerilmektedir. $R^{2}$ ve düzeltilmiş $R^{2}$ değerlerinin birbirlerine yakın olmas1 modellerin istatistiksel olarak önemsiz terimleri içermediğini gösterdiği bildirilmektedir (Koç, 2015). Her bir cevap üzerinde bağımsız değişkenlerin etkisi aşağıda yer alan ayrı başlıklar altında açıklanmıştır.

\section{Toplam fenolik madde üzerine püskürterek kurutma şartlarının etkisi}

Zerdeçal mikrokapsüllerinin toplam fenolik madde miktarı 262.00-464.16 mg/100 g arasinda bulunmuş olup, bağımsız değişkenlerin cevap üzerindeki etkileri Şekil 2'de gösterilmiştir. Grafik incelendiğinde örneklerin toplam fenolik madde miktarının karışımda yer alan taşıyıcı maddelerden çok fazla etkilenmediği, orta sıcaklıklarda yüksek, düşük ve yüksek sıcaklıklarda ise miktarın azaldığı görülmektedir. Ghandehari Yazdi vd. (2021) tarafindan antep fistığı kabuğu fenoliklerinin üç farklı sicaklıkta $\left(140,150\right.$ ve $\left.160^{\circ} \mathrm{C}\right)$ püskürterek kurutma yöntemiyle enkapsüle edildiği çalışmada en yüksek fenolik maddenin $150^{\circ} \mathrm{C}$ 'de elde edildiği bildirilmiştir. Yüksek sıcaklıklarda fenolik madde miktarının azalması bu bileşenlerin ısıya hassas olmalar1 nedeniyle meydana gelen degradasyonla ilişkilendirilirken (Sablania ve Bosco, 2018), düşük sıcaklıklarda ise damlacik yüzeyinde yarı geçirgen zarın hızlı bir şekilde oluşmamasından dolayı çekirdek materyalin tutulumunun istenen düzeyde sağlanamaması ile ilişkilendirilmektedir (Tsali ve Goula, 2018).

\section{Kurutma verimliliği üzerine püskürterek kurutma şartlarının etkisi}

Püskürterek kurutma üzerine yapılan etken maddelerin enkapsülasyonu işlemlerinde, stabil kapsüllerin üretiminin önemli olmasının yanında daha da önemli olan bir diğer husus da kurutma işleminin ne kadar verimde gerçekleştirildiğidir. Yapılan çalışmalar sonucunda laboratuvar ölçekli püskürtmeli kurutucuda kurutma işleminin verim açısından başarılı olarak sayılabilmesi için ürün veriminin en az $\% 50$ olması gerektiği belirtilmiştir (Bhandari vd., 1997; Vidović vd., 2014). Bu çalışma kapsamında püskürterek kurutma yöntemiyle \%70.22-98.92 arasinda verimde zerdeçal mikrokapsülleri elde edilebilmiștir. Püskürterek kurutma sıcaklığının artması ile verimin arttığ1 ve verim üzerinde asıl etkili faktörün taşıyıc1 materyalin olduğu görülmüştür. Taşıyıcı karışımındaki maltodekstrin oranının artması kurutma veriminin de artmasina neden olmuştur (Şekil 2). Zahterin püskürterek kurutulmasını konu alan bir çalışma sonucunda karışımdaki maltodekstrin oranının artmasıyla kurutma veriminin arttığı, verimli sayılabilecek bir kurutma için en az \%10 oranında maltodekstrin kullanılması gerektiği, ancak çok yüksek oranlarda maltodekstrin kullanılması durumunda bitkiden gelen karakteristik, istenilebilecek lezzetin maskelendiği belirtilmiştir (Vidović vd., 2014).

\section{Carr indeks değeri üzerine püskürterek kurutma şartlarının etkisi}

Carr indeks değeri toz ürünlerin akabilirlik özelliği hakkında fikir vermesi açısından önemli bir parametre olarak değerlendirilmektedir. Toz ürünlerin yığın yoğunluğu ve sıkıştırılmış yığın yoğunluklarını kullanarak belirlenen "Carr indeks" değerinin 15'den küçük olması durumunda akabilirlik çok iyi, 15-20 arasında iyi, 20-35 arasında zayıf, 35-45 arasında kötü, 45’ten büyük ise çok kötü olarak tanımlanmaktadır (Carr, 1965). Bu tanımlamaya göre zerdeçal mikrokapsüllerinin Carr indeks değeri sonuçları değerlendirildiğinde "kötü" ve "çok kötü” olarak tanımlanabilecek nitelikte ürünün bulunmadığını söylemek mümkündür (Çizelge 1). Bağımsız değişkenlerin orta noktalarında Carr indeks değeri istenilen şekilde düşük bulunmuş olup, püskürterek kurutma giriş hava sıcaklığı ve 
karışımdaki maltodekstrin oranı arttıkça artış göstermiştir (Şekil 2). Jangam ve Thorat (2010) tarafindan zencefil ekstraktının püskürterek kurutma yöntemi ile toz forma dönüştürülmesinin amaçlandığı çalışmada $120-160^{\circ} \mathrm{C}$ arasındaki
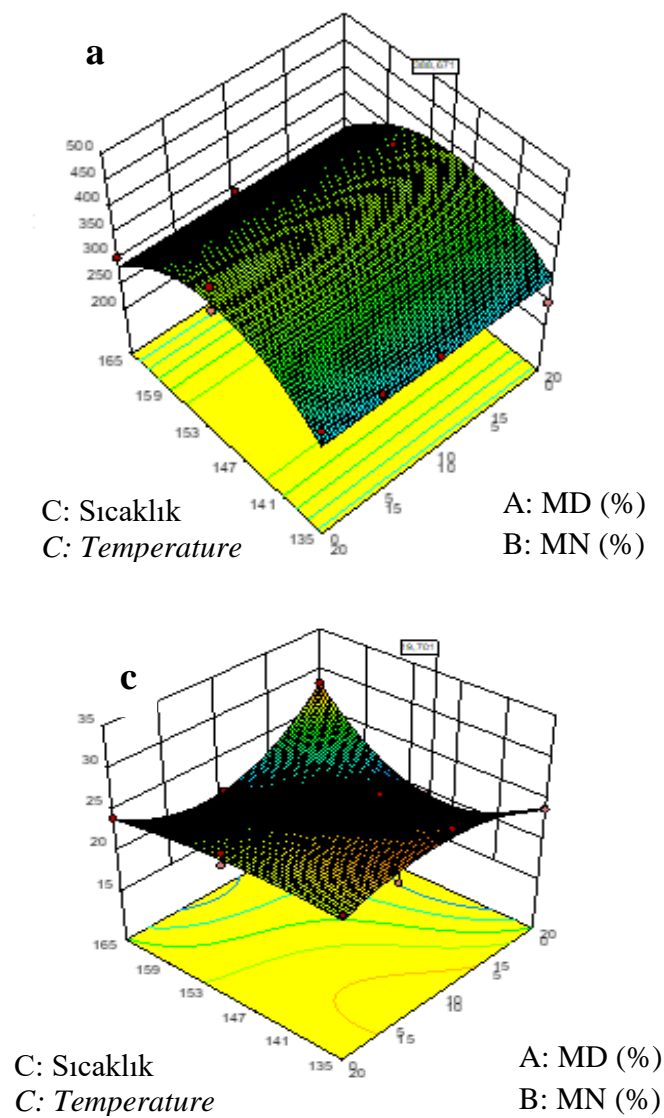

kurutma sıcaklıklarında deneme gerçekleştirilmiş ve çalş̧ma sonucunda bu çalışma ile uyumlu şekilde optimum Carr indeks değerinin $150^{\circ} \mathrm{C}$ elde edilebildiği belirtilmiştir.

C: Sicaklik

C: Temperature

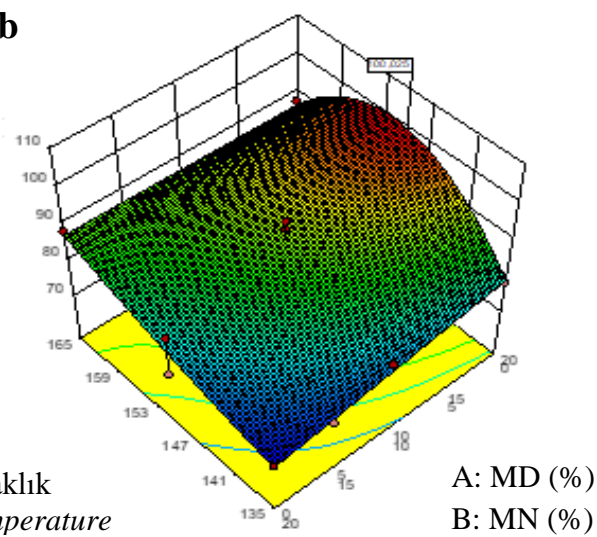

d

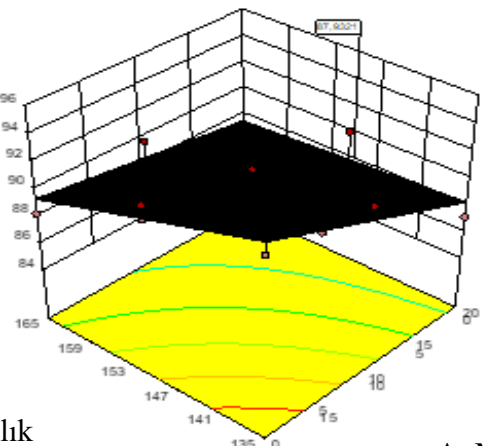

C: Sicaklık

C: Temperature

$\mathrm{A}: \mathrm{MD}(\%)$

$\mathrm{B}: \mathrm{MN}(\%)$

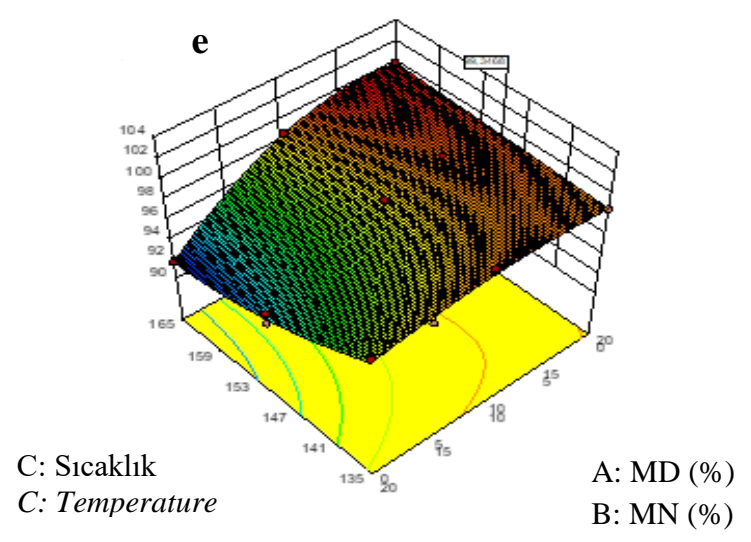

Şekil 2. Püskürterek kurutma yöntemi ile elde edilen zerdeçal mikrokapsüllerinin (a: Toplam fenolik madde miktarı, b: Kurutma verimliliği, c: Carr indeks, d: Hue açısı değeri, e: Çözünürlük değeri) yanıt yüzey grafikleri

Figure 2. Response surface graphs of turmeric microcapsules obtained by spray drying (a: total phenolic content, $b$ : Drying yield, c: Carr index, d: Hue angle value, e: Solubility value) 
Hue açıs1 değeri üzerine püskürterek kurutma şartlarının etkisi

Zerdeçal mikrokapsüllerinin $\% 1$ (ağırlık/hacim)'lik su ekstraktının Hue açısı değeri ölçülerek zerdeçala özgü sarımsı rengin püskürterek kurutma işlem koşulları ile değişimi incelenmiştir. Hue açısının $0^{\circ}$ olması kırmızıyı, $90^{\circ}$ olması sarıyı, $180^{\circ}$ olması yeşili ve $270^{\circ}$ olması ise ürünün mavi renkte olduğunu ifade etmekte, bu açı değerlerinin aralarına denk gelen kısımlarda ise ara renkler oluşmaktadır (Tasova ve Ozkurt, 2018). Şekil 2'de verilen bağımsız değişkenlerin Hue açısı değeri üzerindeki etkisini gösteren grafik incelendiğinde karışımdaki modifiye nişasta oranının artması ve kurutma sıcaklığının azalması ile Hue açısı değerinin artarak $90^{\circ}$ ye yaklaştığ sonucuna ulaşılmıştır. Bu durum yüksek kurutma sıcaklıklarında zerdeçalın sarı renginden sorumlu olan kurkuminoidlerin degradasyonuna bağlı olarak sarı rengin azalması ile ilişkilendirilmiştir. Kurkumin ekstraktının 110 ve $150^{\circ} \mathrm{C}^{\prime} \mathrm{de}$ püskürterek kurutulduğu çalışma sonuçları düşük sıcaklıkta yapılan kurutma işlemi sonrasında kurkumin kazanımının daha yüksek olduğu sonucuna ulaşılmıştır (Liu vd., 2016).
Çözünürlük değeri üzerine püskürterek kurutma şartlarının etkisi

Çizelge 1'de verilen zerdeçal tozlarına ait çözünürlük sonuçları incelendiğinde değerlerin \%91.70-100 arasında değiştiği, elde edilen tozların suda iyi çözünürlük özelliğine sahip olduğu görülmektedir. Tüm örnekler suda iyi çözünürlük özelliği gösterse de özellikle karışımdaki maltodekstrin oranının artmasıyla çözünürlük değerinin artış gösterdiği sonucuna ulaşılmıştır (Şekil 2). Balc1-Torun (2019), aroma maddelerini püskürterek kurutma yöntemiyle toz forma dönüştürdügü çalışmada, taşıyıcı materyal olarak maltodekstrin ve modifiye nişastanın birlikte kullanıldığı durumda bu çalışma ile benzer şekilde maltodekstrin oranının artmasıyla örneklerin çözünürlük değerlerinin arttığını tespit etmiştir.

Teorik olarak belirlenen optimum koşulların deneysel olarak doğrulanması

Optimum işlem koşulları olarak karışımda \%15 oranında maltodekstrin, $\% 5$ oraninda modifiye nişasta kullanılması gerektiği ve püskürterek kurutma hava giriş sıcaklığının $156^{\circ} \mathrm{C}$ olması gerektiği sonucuna ulaşılmıştır. Optimum koşullarda test edilen parametrelerin tahminlenen değerleri deneysel olarak da doğrulanmış ve aradaki sapmaları da gösteren sonuçlar Çizelge 3'de verilmiştir.

Çizelge 3. Zerdeçal mikrokapsüllerinin deneysel ve teorik olarak elde edilen analiz sonuçları Table 3. Experimental and theoretical analysis results of turmeric microcapsules

\begin{tabular}{|c|c|c|c|c|c|}
\hline & $\begin{array}{l}\text { Toplam fenolik madde } \\
\text { miktar1 (mg/100g } \\
\text { mikrokapsül) } \\
\text { Total phenolic content } \\
\text { (mg/100 g microcapsule) }\end{array}$ & $\begin{array}{l}\text { Verim } \\
(\%) \\
\text { Yield } \\
(\%)\end{array}$ & $\begin{array}{l}\text { Carr indeks } \\
\text { Carr index }\end{array}$ & $\begin{array}{c}\text { Hue açis1 } \\
\left(\mathrm{h}^{\circ}\right) \\
\text { Hue angle } \\
\left(b^{\circ}\right)\end{array}$ & $\begin{array}{c}\text { Çözünürlük } \\
(\%) \\
\text { Solubility } \\
(\%)\end{array}$ \\
\hline $\begin{array}{l}\text { Teorik } \\
\text { Theoretical }\end{array}$ & 380.56 & 95.08 & 26.04 & 88.60 & 99.20 \\
\hline $\begin{array}{l}\text { Deneysel } \\
\text { Experimental }\end{array}$ & 392.56 & 91.10 & 26.37 & 87.50 & 97.40 \\
\hline $\begin{array}{l}\text { Farklilık (\%) } \\
\text { Difference (\%) }\end{array}$ & 3.15 & 4.19 & 1.27 & 1.24 & 1.82 \\
\hline
\end{tabular}

Optimum koşullarda teorik ile deneysel veriler arasındaki farkın \%15'ten az olmas1 beklenmektedir (Myers vd., 2011). Bu anlamda püskürterek kurutma tekniğiyle zerdeçal enkapsülasyonunda bu çalışma için optimum koşulların deneysel olarak doğrulanabildiğini söylemek mümkündür. 


\section{SONUÇ}

Zerdeçal, içeriğindeki özellikle kurkumin başta olmak üzere fenolik maddelerden dolayı sağlıklı yaşamın öneminin daha da fazla anlaşıldığı günümüzde tüketimi en fazla artış gösteren ürünlerden biri olmuştur. Özellikle zerdeçal bazlı ekstraktların fonksiyonel özellik kazandırılmak istenen gidalara katkılanma eğiliminde olunduğu görülmektedir. Bu anlamda su bazlı bir ekstrakt elde etmek için uygun koşulların belirlenerek elde edilen ekstraktun kolay kullanılabilir ve stabil depolanabilir bir formda üretilmesi oldukça önemlidir. Bu makalede de zerdeçal fenolikleri üzerine ekstraksiyon şartlarının etkisi araştırılmıs, elde edilen ekstraktın toz forma dönüştürülmesi için kullanılan püskürterek kurutma yönteminin taşı1ıcı madde ve kurutma giriş sıcaklığı açısından en uygun şartları belirlenmiştir. Çalışma sonuçları, ultrases desteğiyle geleneksel yönteme göre çok daha düşük sıcaklıkta $\left(25^{\circ} \mathrm{C}\right)$ ve kısa sürede $(2$ dak.) daha fazla fenolik maddenin (1436.68 mg GAE/100 g KM) ekstrakte edilebileceğini göstermiştir. Püskürterek kurutma işleminin optimum koşulları olarak karışımda $\% 15$ oranında maltodekstrin, $\% 5$ oranında modifiye nişasta kullanılmas1 gerektiği ve püskürterek kurutma hava giriş sicaklığının $156^{\circ} \mathrm{C}$ olması gerektiği sonucuna ulaşı1mıştır. Bu çalışmada ülkemizde yetiştiriciliği yapılmaya başlanan zerdeçal rizomları kullanılmış olup, yetiştiriciliğinin ve kullanımının yaygınlaşmasında katma değerli ürünlerin üretimi ile ilgili bilimsel çalışmaların daha fazla yapılması oldukça önemlidir.

\section{ÇIKAR ÇATISMASI BEYANI}

$\mathrm{Bu}$ makalede yer alan yazarların, başka kişiler ve/veya kurumlar ile çıkar çatışması bulunmamaktadir.

\section{YAZARLARIN KATKISI}

Keziban Kübra GÜNGÖR, Gülderen COŞGUN ve Merve ÖZDEMIR, analizlerin yürütülmesi, sonuçların istatistiksel değerlendirilmesi ve makale taslağının yazım sürecinde katk1 sağlamışlar; Mehmet TORUN, denemenin kurulması, analiz sonuçlarının kontrol edilerek değerlendirilmesi, taslak makalenin düzeltilmesi ve çalışma için maddi kaynak temini aşamalarında katk1 sağlayarak yüksek lisans öğrencilerine danışmanlık yapmıştır.

\section{TEŞEKKÜR}

Antalya Gazipaşa ilçesinde zerdeçal üreticiliği yapan ve çalışmanın materyallerini temin eden Süleyman TUNCER'e teşekkür ederiz.

\section{KAYNAKLAR}

Aniesrani Delfiya, D. S., Thangavel, K., Natarajan, N., Kasthuri, R., Kailappan, R. (2015). Microencapsulation of turmeric oleoresin by spray drying and in vitro release studies of microcapsules. J Food Process Eng, 38(1): 37-48, doi: 10.1111/jfpe.12124.

Balc1-Torun, F. (2019). Farklı enkapsülasyon yöntemleri kullanılarak elde edilen aroma kapsüllerinin depolama stabilitesinin ve gıda katkı maddesi olarak kullanımının araştırılması. Akdeniz Üniversitesi Fen Bilimleri Enstitüsü Gıda Mühendisliği Anabilim Dalı Doktora Tezi, Antalya, Türkiye, $182 \mathrm{s.}$

Banožić, M., Babić, J., Jokić, S. (2020). Recent advances in extraction of bioactive compounds from tobacco industrial waste-a review. Ind Crops Prod, 144, doi: 10.1016/j.indcrop.2019.112009.

Bhandari, B. R., Dumoulin, E. D., Richard, H. M. J., Noleau, I., Lebert, A. M. (1992). Flavor encapsulation by spray drying: application and linalyl acetate. Food Rev Int, 57 (1): 217-221, doi: 10.1111/j.1365-2621.1992.tb05459.x.

Bhandari, B.R., Datta, N., Howes, T. (1997). Problems associated with spray drying of sugarrich foods. Dry Technol, 15(2): 671-684, doi: 10.1080/07373939708917253.

Beristain, C., Garcia, H., Vernon-Carter, E. (2001). Spray-dried encapsulation of cardamom (Elettaria cardamomum) essential oil with mesquite (Prosopis juliflora) gum. LWT-Food Sci and Technol (N Y), 34 (6): 398-401, doi: 10.1006/fstl.2001.0779.

Bucurescu, A., Blaga, A.C., Estevinho, B. N., Rocha, F. (2018). Microencapsulation of Curcumin by a Spray-Drying Technique Using Gum Arabic as Encapsulating Agent and Release 
Studies. Food Bioproc Tech, 11(10): 1795-1806, doi: 10.1007/s11947-018-2140-3.

Cano-Higuita, D. M., Vélez, H. A. V., Telis, V. R. N. (2015). Microencapsulation of turmeric oleoresin in binary and ternary blends of gum Arabic, maltodextrin and modified starch, Cienc Agrotecnol, 39(2): 173-182, doi: 10.1590/S141370542015000200009 .

Carneiro, H. C. F., Tonon, R.V., Grosso, C. R. F., Hubinger, M. D. (2013). Encapsulation efficiency and oxidative stability of flaxseed oil microencapsulated by spray drying using different combinations of wall materials. J Food Eng, 115(4): 443-451, doi: 10.1016/j.jfoodeng.2012.03.033.

Carr, R.L. (1965). Evaluating flow properties of solids. Chem Eng, 72: 163-168.

Coronel-Delgado, A. Y., Ciro-Velásquez, H. J., Restrepo-Molina, D. A. (2017). Secado por aspersión de extractos líquidos de cúrcuma: Evaluación del proceso y propiedades de calidad del producto. Ing Compet, 19(1): 219, doi: 10.25100/iyc.v19i1.2146.

Cortés-rojas, D. F., Souza, C. R. F., Olivera, W. P. (2014). Chemical Engineering Research and Design Optimization of spray drying conditions for production of Bidens pilosa $\mathrm{L}$. dried extract. Chem Eng Res Des, 93: 366-376, doi: 10.1016/j.cherd.2014.06.010.

Ferreira, S., Piovanni, G. M. O., Malacrida, C. R., Nicoletti, V. R. (2019). Influence of emulsification methods and spray drying parameters on the microencapsulation of turmeric oleoresin. Emir J Food Agric, 31(7): 491-500, doi: 10.9755/ejfa.2019.v31.i7.1968.

Hailemichael, G., Zakir, M. (2021). Pre- and postharvest practices influencing yield and quality of turmeric (Curcuma longa L.) in Southwestern Ethiopia: A review. Afr J Agric Res, 17(8): 10961105, doi: 10.5897/ajar2020.15409.

Ghandehari Yazdi, A. P., Barzegar, M., Sahari, M. A., Gavlighi, H. A. (2021). Encapsulation of pistachio green hull phenolic compounds by spray drying. J Agric Sci Technol, 23(1): 51-64.

Goëlo, V., Chaumun, M., Goncalves, A., Estevinho, B. N., Lepaba, F. R. (2020).
Polysaccharide-based delivery systems for curcumin and turmeric powder encapsulation using a spray-drying process. Powder Technol, 370: 137-146, doi: 10.1016/j.powtec.2020.05.016.

Gomes, J. V. P., Oliveira, L. A., Francisquini, J. A., Anunciação, P. C., Stephani, R., Oliveira, L. F., Perrone Í. T., Carvalho, A. F., Lucia, C. M. D. (2020). Morphological characterization of whey protein concentrate admixture of microencapsulated curcumin by spray drying. $J$ Food Process Preserv, 45(2): 1-8, doi: 10.1111/jfpp.15141.

Güngör, K. K. (2021). Balkabağ1 kabuğundan çevre dostu yöntemler kullanılarak $\beta$-karoten ekstraksiyonu ve elde edilen ekstraktın farklı yöntemlerle enkapsülasyonu. Akdeniz Üniversitesi Fen Bilimleri Enstitüsü Gıda Mühendisliği Anabilim Dalı Yüksek Lisans Tezi, Antalya, Türkiye, $69 \mathrm{~s}$.

Jangam, S. V., \& Thorat, B. N. (2010). Optimization of spray drying of ginger extract. Dry Technol, 28(12), 1426-1434.

Koç, M. (2015). Farklı kurutma yöntemleri ile bal tozu üretim koşullarının optimize edilmesi ve depolama stabilitesinin belirlenmesi. Ege Üniversitesi Fen Bilimleri Enstitüsü Gıda Mühendisliği Anabilim Dalı Doktora Tezi, İzmir, $202 \mathrm{~s}$.

Komonsing, N., Khuwijitjaru, P., Nagle, M., Müller, J., Mahayothee, B. (2021). Effect of drying temperature together with light on drying characteristics and bioactive compounds in turmeric slice. J Food Eng, doi: 10.1016/j.jfoodeng.2021.110695.

Köprüalan, Ö., İlter, I., Akyll, S., Koç, M., Kaymak Ertekin, F. (2021). Improving the stability of oily turmeric extract by microencapsulation using spray drying technique. J Dispers Sci Technol, doi: 10.1080/01932691.2021.1929290.

Kshirsagar, A. C., Yenge, V. B., Sarkar, A., Singhal, R. S. (2009). Efficacy of pullulan in emulsification of turmeric oleoresin and its subsequent microencapsulation. Food Chem, 113(4): 1139-1145, doi: 10.1016/j. 
Liu, W., Chen, X. D., Cheng, Z. (2016). On enhancing the solubility of curcumin by microencapsulation in whey protein isolate via spray drying. J Food Eng, 169: 189-195, doi: 10.1016/j.jfoodeng.2015.08.034.

Mathew, D., Hsu, W. L. (2018). Antiviral potential of curcumin. J Funct Foods, 40: 692-699, doi: 10.1016/j.jff.2017.12.017.

Myers R. H., Montgomery D. C., AndersonCook, C. M. (2011). Response Surface Methodology : Process and Product Optimization Using Designed Experiments. 3th Edition, John Wiley \& Sons, Inc., New York.

Nisar, T., Iqbal, M., Raza, A., Safdar, M., Iftikhar, F., Waheed, M. (2015). Estimation of Total Phenolics and Free Radical Scavenging of Turmeric (Curcuma longa). American-Eurasian J. Agric. \& Environ. Sci, 15(7): 1272-1277, doi: 10.5829/idosi.aejaes.2015.15.7.9527.

Özgüner-Kabak, M. (2019). Meyan kökünde bulunan bazı biyoaktif bileşenlerin ekstraksiyonu üzerine farklı yöntemlerin etkisinin araştırılması. Akdeniz Üniversitesi Fen Bilimleri Enstitüsü Gıda Mühendisliği Anabilim Dalı Yüksek Lisans Tezi, Antalya, Türkiye, $70 \mathrm{~s}$.

Papillo, V. A., Arlorioa, M., Locatellia, M., Fusob, L., Pellegrini, N., Foglianod, V. (2019). In vitro evaluation of gastro-intestinal digestion and colonic biotransformation of curcuminoids considering different formulations and food matrices. J Funct Foods, 59: 156-163, doi: 10.1016/j.jff.2019.05.031.

Patel, S. S., Pushpadass, H. A., Franklin, M. E. E., Battula, S. N., Vellingiri, P. (2021). Microencapsulation of curcumin by spray drying: Characterization and fortification of milk. J Food Sci Technol, doi: 10.1007/s13197-021-05142-0.

Sablania, V., Bosco, S. J. D. (2018). Optimization of spray drying parameters for Murraya koenigii (Linn) leaves extract using response surface methodology. Powder Technol, 335: 35-41, doi: 10.1016/j.powtec.2018.05.009.

Sahin Nadeem, H., Torun, M., Özdemir, F. (2011). Spray drying of the mountain tea (Sideritis stricta) water extract by using different hydrocolloid carriers. Food Sci Technol, 44: 7: 16261635, doi: 10.1016/j.lwt.2011.02.009.

Sana, S., Arshad, M. U., Saeed, F., Ahmad, R. S., Imran, A., Tufail, T. (2019). Nutritional characterization of cinnamon and turmeric with special reference to their antioxidant profile Nutritional characterization of cinnamon and turmeric with special reference to their antioxidant profile. Int J Biosci, 15(4): 178-187, doi: 10.12692/ijb/15.4.178-187.

Singh, R., Feroze, S.M., Kumar, S., (2020). Production of Turmeric in North East Hill Region of India: A Value Chain Analysis. Indian J Agric Econ, 75(4): 359-374.

Škerget, M., Kotnik, P., Hadolin, M., Hraš, A. R., Simonič, M., \& Knez, Ž. (2005). Phenols, proanthocyanidins, flavones and flavonols in some plant materials and their antioxidant activities. Food Chem, 89(2): 191-198, doi: 10.1016/j.foodchem.2004.02.025.

Şahin Nadeem, H., Torun, M., Özdemir, F. (2011). Spray drying of the mountain tea (Sideritis stricta) water extract by using different hydrocolloid carriers. LWT - Food Sci Technol, 44(7): 1626-1635, doi: 10.1016/j.lwt.2011.02.009.

Tanvir, E. M., Hossen, M. S., Hossain, M. F., Afroz, R., Gan, S. H., Khalil, M. I., Karim, N. (2017). Antioxidant properties of popular turmeric (Curcuma longa) varieties from Bangladesh. J Food Qual, 1-8, doi: 10.1155/2017/8471785.

Tasova, M., Özkurt, M. (2018). Korunga ( Onobrychis sativa L .) Tohumlu ğunun Baz1 Biyoteknik ve Renk Özelliklerinin Belirlenmesi. Int J Life Sci Biotechnology, 1(2): 48-58, doi: 10.38001/ijlsb.475100.

Tayyem, R. F., Heath, D.D., Al-Delaimy, W. K., Rock, C.L. (2006). Curcumin content of turmeric and curry powders. Nutr Cancer, 55(2): 126-131, doi: 10.1207/s15327914nc5502_2.

Torun M., Dincer C., Topuz A., Sahin-Nadeem H., Ozdemir F. (2015). Aqueous extraction kinetics of soluble solids, phenolics and flavonoids from sage (Salvia fruticosa Miller) leaves. 
J Food Sci Technol, 52(5): 2797-2805, doi: 10.1007/s13197-014-1308-8.

Tsali, A., Goula, A. M. (2018). Valorization of grape pomace: Encapsulation and storage stability of its phenolic extract. Powder Technol, 340: 194-207. doi: 10.1016/j.powtec.2018.09.011.

Vidović, S. S., Vladić, J. Z., Vaštag, Ž. G., Zeković, Z. P., Popović, L. M. (2014). Maltodextrin as a carrier of health benefit compounds in Satureja montana dry powder extract obtained by spray drying technique. Powder Technol, 258, 209-215, doi: 10.1016/j.powtec.2014.03.038.
Yang, Q. Q., Chenga, L. Z., Zhangb, T., Yaronc, S., Jiangd, H. X., Suia, Z. Q., Corkea, H. (2020). Phenolic profiles, antioxidant, and antiproliferative activities of turmeric (Curcuma longa). Ind Crops Prod, 152: 1-8, doi: 10.1016/j.indcrop.2020.112561.

Zhang, N., Li, H., Jia, J., He, M. (2015). Antiinflammatory effect of curcumin on mast cellmediated allergic responses in ovalbumin-induced allergic rhinitis mouse. Cell Immunol, 298(1-2): 8895, doi: 10.1016/j.cellimm.2015.09.010. 